\title{
EOSINOPHIL GRANULOCYTES AND PLASMA CELLS IN JEJUNAL MUCOSA OF DOGS NATURALLY INFECTED WITH OR WITHOUT INTESTINAL PARASITES
}

\author{
$\ddot{U l k e r}$ EREN $N^{\prime}$ \\ Mustafa SANDIKÇII \\ Muharrem BALKAYA2
Şadiye ERG $\ddot{U} L D \ddot{U} R E N L E R^{\prime}$
}

\begin{abstract}
Barsak parazitleri ile doğal enfekte ve enfekte olmayan köpeklerin jejunum mukozasında eozinofil granulositler ve plazma hücreleri
\end{abstract}

\begin{abstract}
Özet: Bu araştıma, barsak parazitleri ile doğal enfekte ve enfekte olmayan köpeklerin jejunum mukozasında eozinofil granulositler ve plazma hücrelerinin dağllmlarının belirlenmesi amacıyla gerçekleştirildi. Ayrica perifer kanda total liokosit ve eozinofil granulosit saylları da belirlendi. Araştırmada, barsak parazitleri ile doğal enfekte olduklan belirlenen 7 ve gaitasinda parazit belirlenemeyen 4 adet olmak üzere toplam 11 adet, belirgin bir ırk özelliği göstermeyen köpek kullanıldı.

Köpeklerin jejunumundan doku örnekleri operatif olarak alındı. Doku örneklerinin tespiti için \%10 tamponlu nötr formalin kullanıldı. Kesitler eozinofil granulositlerin demonstrasyonu için Congo red, plazma hücrelerinin demonstrasyonu için metil green pyronin ile boyandllar. Her iki hücre de jejunal mukozada villus-kript ünitede sayıldı. Perifer kan lökosit ve eozinofil granulosit konsantrasyonlart standart tekniklerle hemositometrede gerçekleştirildi.

Incelenen doku kesitlerinde eozinofil granulositlerin lamina propriya'da özellikle villuslarda, kriptlerin bazal kısımlarında ve lamina subglandularis'te yoğun olarak bulunduklart görüldü. Ayrıca genellikle kriptlerde ve nadiren villusların tabanında intraepiteliyal eozinofil granulositlerin bulunduğu gözlendi. Bazı eozinofil granulositlerin de barsak lumeninde bulunduklart dikkati çekti. Pironinofilik hücrelerin özellikle villuslarda yoğun olarak bulunduklarl, daha az. olarak da kript bölgesinde yer aldıkları gözlendi.
\end{abstract}

Barsak parazitleri ile enfekte olan ve gaitasinda parazit belirlenemeyen gruplar arasında total lökosit ve kan eozinofil granulosit konsantrasyonlart ile doku eozinofil granulositleri ve plazma hücreleri için elde edilen veriler karşlaştırıldı̆̆ında, sadece enfekte grupta doku eozinofil granulosit sayılarının fazlalı̆̆ anlamlı bulundu $(p<0.05)$.

Anahtar kelimeler: Eozinofil granulosit, intestinal parazitozis, jejunum, köpek, plazma hücresi

1. The University of Adnan Menderes, Faculty of Veterinary Medicinc, Department of Histology- Embryology. Aydin/ TÜRKIYE

2. The University of Adnan Menderes, Faculty of Veterinary Medicine, Department of Physiology, Aydin/TÜRKIYE 
Summary: This study was carried out to determine the distribution of eosinophil granulocytes and plasma cells in the jejunal mucosa of the dogs naturally infected or not infected with intestinal parasites. In addition, the total leukocyte and eosinophil granulocyte concentrations were determined in peripheral blood. For this purposes, 11 mongrel dogs were used where 7 of them were determined to be infected naturally with intestinal parasites, and in 4 of them there were no evidence of an actual intestinal parasitic infection.

The tissue specimens of the jejunum were obtained by abdominal surgery from both groups. Specimens were fixed with $10 \%$ neutral buffered formalin. The tissue sections were stained with either Congo red for eosinofil granulocytes or methyl green pyronin for plasma cells. Tissue sections were examined by light microscopically. Both cells were counted in villus-crypt units of jejunal mucosa. The determination of the leukocyte and eosinophil granulocyte concentrations in peripheral blood were carried out from blood samples with standart technics.

It was observed that eosinophil granulocytes were located in lamina propria of jejunal mucosa, especially within villus intestinalis, basal parts of crypts and lamina subglandularis. Furthermore, eosinophil granulocytes were also located intraepithelially in crypts and rarely at the base of the villus. Some eosinophil granulocytes were also seen within intestinal lumen. The pyroninophilic cells were identified in jejunum. They were intensively prominent in villus intestinales, but they were found also in crypts in a lesser extent.

A t-Test for independent groups showed that the eosinophil granulocyte count in jejunal mucosa was higher in parasitized dogs than in jejunal mucosa of noninfected dogs ( $p<0.05)$. But there were no significant differences in concentrations of leukocytes and eosinophil granulocytes in peripheral blood, as well a.s in the number of plasma cells in jejunal mucosa when compared the dogs with intestinal parasite with those showing no parasite in feces.

Key words: Dog, eosinophil granulocyte, intestinal parasitosis, jejunum, plasma cells.

\section{Introduction}

Eosinophil granulocytes are cells with numerous membrane-bound specific granules some of them having usually electron-dense cristalloid internum, crystalloid cores, also called "central core". These specific granules contain lysosomal enzymes as well as most of the cationic protcins unique to eosinophil granulocytes. The cristalloid corc of the granule, when present, composed of major basic protein (MBP), and the noncore matrix contains cosinophil cationic protein (ECP), eosinophil peroxidase and eosinophil-derived neurotoxin $(12,31)$.
Eosinophil granulocytes defend against large, nonphagocytable organisms, most notably the multicellular helminthic parasites (6), fungal agents (20) and foreing proteins (4). One of the components of lysosomal granules of eosinophil granulocytes, the MBP, is a potent cytotoxin for certain parasites (28). Eosinophil granulocytes react to the helmiths when a sensitivity to the protein of the parasite has developed (allergic state) or the protein or secretory product of the parasite is relcased in the body. Initial binding of eosinophil granulocytes to parasitic targets can be mediated by antiparasite IgG or IgE antibodies or by $\mathrm{C} 3 \mathrm{~b}$ deposited on the surfaces of parasites 
(38). Although single-celled protozoan parasites can bc killed by eosinophil granulocytes, eosinophilia is heightened not by infections with protozoa except Isospora bclli but rather by helminthic parasites (6). Eosinophil granulocytes can kill a wide number of helminthic parasites, especially in their larval stages $(6,21,36)$. Although other cells can also kill such parasites, eosinophil granulocytes are particularly toxic to helminths for several reasons. First, the cationic proteins they deposite after binding to the surfacc of the parasite, especially MBP and ECP are potent helminthotoxins (1). Eosinophil peroxidase generates hypohalous acids that also kill parasites. Finally, cosinophil oxydative products also mediate helminthotoxicity $(6,45)$.

Plasma cells are regularly found in the lamina propria of the gastro-intestinal tract according to the demand for local antibody production (33). Investigations of the canine intestinal tract have shown the immunoglobulin (Ig)-positive cells in either small or large intestine $(15,18,43)$. But, there is no difference in the number of plasma cells in different intestinal regions under normal circumstances (15).

In many parasitic discase of intestine both plasma cells and eosinophil granulocytes are prominent $(8,34,35,46)$. There is an interaction between these two cell types in opsonisation procedure of parasitic agents. Eosinophil granulocytes undergo exocytosis to expell their granular constituents when they come in close contact with an opsonised (antibody- and complement-coated) parasite (38).

In an another study in which the same animals were used, we found that the number of mast cells were significantly higher in naturally infected dogs compared with uninfected dogs (13). Also, the aim of the present study was to identify the distribution of cosinophil granulocytes and plasma cells within jejunal mucosa of the dogs naturally infected with intestinal parasites. In addition, the total leukocyte and eosinophil granulocyte concentrations were also determined in peripheral blood.

\section{Materials and Methods}

\section{Animals}

In this study, 11 mongrel dogs (6 females and 5 males) were used weighing $12-24 \mathrm{~kg}$ and age of 1 to 2,5 . The dogs had been used in the other study (13). The dogs were divided into two groups; the first group was determined as naturally infected with intestinal parasites $(n=7)$, and the second group showed no an actual intestinal parasitic infection $(n=4)$.

\section{Surgery}

Jejunal biopsies were obtained from both groups by abdominal surgery. For this purpose the dogs werc anesthesized with $10 \mathrm{mg} / \mathrm{kg}$ ketamin hydrochlorur (Ketanes, Alke) given intramuscularly. Jejunal biopsies were removed and than, additional anesthesia was induced with $2 \mathrm{mg} / \mathrm{kg}$ i.m. xylazin hidrochlorur (Rompun ${ }^{\circledR}$, Baycr). Ampisilin trihydrat (5-10 $\mathrm{mg} / \mathrm{kg}$, Alfasilin /Abfar) was used for three days as antibiotic to protect possible infections in post-operative period which was started at the day of operation.

\section{Tissue processing and staining}

Tissue samples were fixed in $10 \%$ neutral buffered formaline (NBF) for 24 hours, and than embedded in parafin. Serial $5 \mathrm{~mm}$ thick sections were cut with $30 \mathrm{~mm}$ intervals. The tissue sections were stained with either Congo red for eosinophil granulocytes (17) or with methyl green pyronin for plasma cells (10).

\section{The counting of cells in tissue sections}

For counting the cells, the mucosa was diveded into "villus-cript" (VC) units. The number of eosinophils and plasma cells lying between two gland crypts and in the lamina propria of the villus above were counted. The 
whole area comprised a VC unit and was delimited basally by the muscularis mucosa (27). The cosinophils and plasma cells at three VC units ( $x 400$ magnification) werc counted for cach section and five seperatc slides were counted for cach tissue block.

\section{Blood sampling and determination of concentrations of leukocytes and eosinophil granulocytes}

The blood samples were withdrawn from each dog into the test tube with EDTA before anaesthcsia, and eosinophil granulocytes and leukocyte counts were carried out within following 2 hours. Leukocyte counts were determined in improved Neubauer hemocytometry with the standard technique using a solution ad modum Türk (44), and cosinophil granulocyte concentration was determined in Fuchs-Rosenthal hemocytometry with a solution ad modum Pilot (32).

\section{Statistical evaluation}

The data were statistically evaluated by t-Test for unpaired groups using SPSS computer program (37).

\section{Results}

In grup I, the dogs were naturally infected with intestinal parasites (Table 1).

The total white blood cell and eosinophil granulocytc consentrations are seen in Table 2 .

The tissue sections were examined light microscopically. It was seen that eosinophil granulocytes and precursors were located intensively in lamina propria of jcjunal mucosa, especially within villus intestinales (Figure 1), in basal parts of crypts and in lamina subglandularis (Figure 2). Furthermore, eosinophil granulocytes were located also intracpithelially, especially in crypts and rarcly

Table 1. The intestinal parasites of naturally infected dogs.

Tablo 1. Doğal enfekte köpeklerin barsak parazitleri.

\begin{tabular}{|c|c|c|c|c|c|c|}
\hline \multirow{3}{*}{$\begin{array}{l}\text { Animal } \\
\text { No } \\
1\end{array}$} & \multicolumn{4}{|c|}{ Helmint (number/ oocyte count) } & \multirow{2}{*}{\multicolumn{2}{|c|}{ Protozoon (oocyst count) }} \\
\hline & \multicolumn{2}{|l|}{ Nematod } & \multicolumn{2}{|l|}{ Cestod } & & \\
\hline & $\begin{array}{l}\text { Uncinaria stenocephala } \\
\text { Toxocara canis }\end{array}$ & $\begin{array}{c}3 / 1100 \\
21\end{array}$ & Dipylidium caninum & $5 / 1150$ & Isospora spp. & 500 \\
\hline 2 & Toxocara canis & $8 / 20(0)(0)$ & - & & - & \\
\hline 3 & - & & Dipylidium caninum & 15() 0 & Isospora spp. & 350 \\
\hline 4 & - & & Cestod & $\begin{array}{l}\text { In tissue } \\
\text { sections }\end{array}$ & - & \\
\hline 5 & Toxocara canis & ll & Dipylidium caninum & $23 / 250$ & Isospora spp. & $2(x)$ \\
\hline 6 & - & & Taenia spp. & 1400 & & \\
\hline 7 & Toxocara canis & $2 / 500$ & - & & Isospora spp. & 100 \\
\hline
\end{tabular}

Table 2. Total leukocyte and eosinophil granulocytc concentrations in peripheral blood of dogs (per ml of blood). Tablo 2. Köpeklerde perifer kanda, ml'de total lökosit ve cozinofil granulosit konsantrasyonları

\begin{tabular}{|l|c|c|c|r|r|r|}
\hline Groups & \multicolumn{3}{|c|}{ Leukocytes } & \multicolumn{3}{c|}{ Eosinophil granulocytcs } \\
\hline & $X$ & \pm & SEM & $X$ & \pm & SEM \\
\hline Group I $(\mathrm{n}=7)$ & 11226 & & 2486 & 84.00 & & 17.40 \\
\hline Group II $(\mathrm{n}=4)$ & 12219 & & 3778 & 63.86 & & 43.3 \\
\hline
\end{tabular}




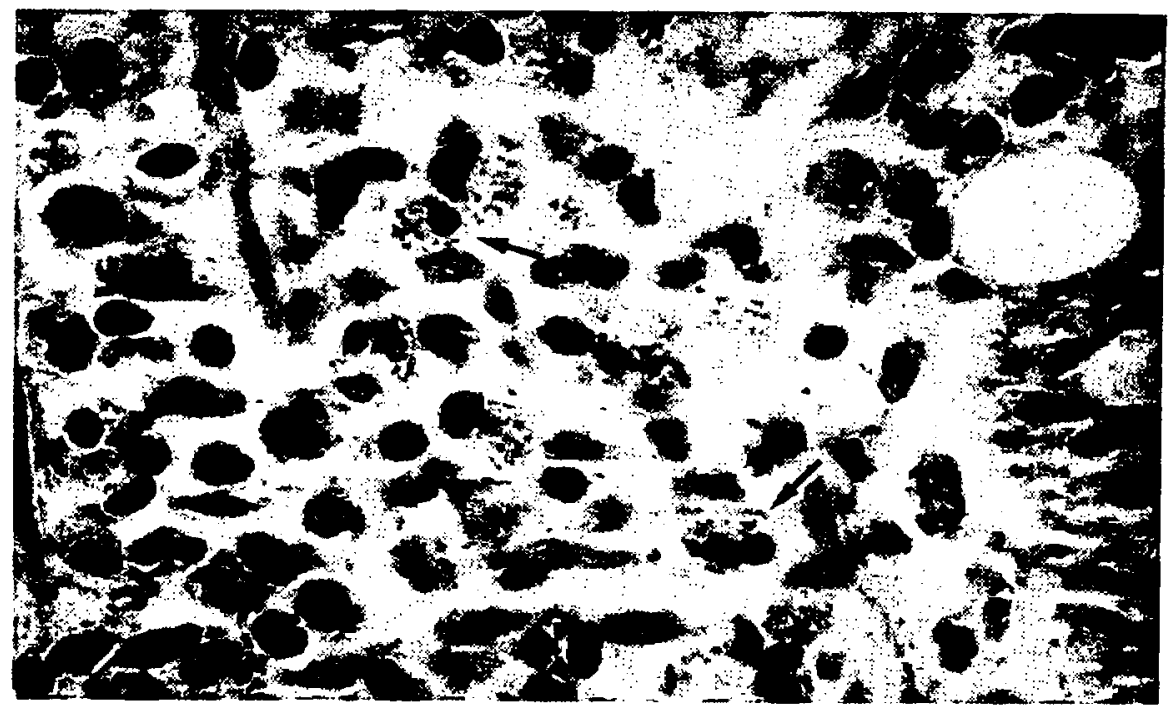

Figure 1. Eosinophil granulocytes observed in villus intesunales (arrow v). (impored red $x \mid 240$. Sckil l. Villus intestinalis'de gözlenen eozinofil granulositler (oklar) Congo red. $\times 1240$

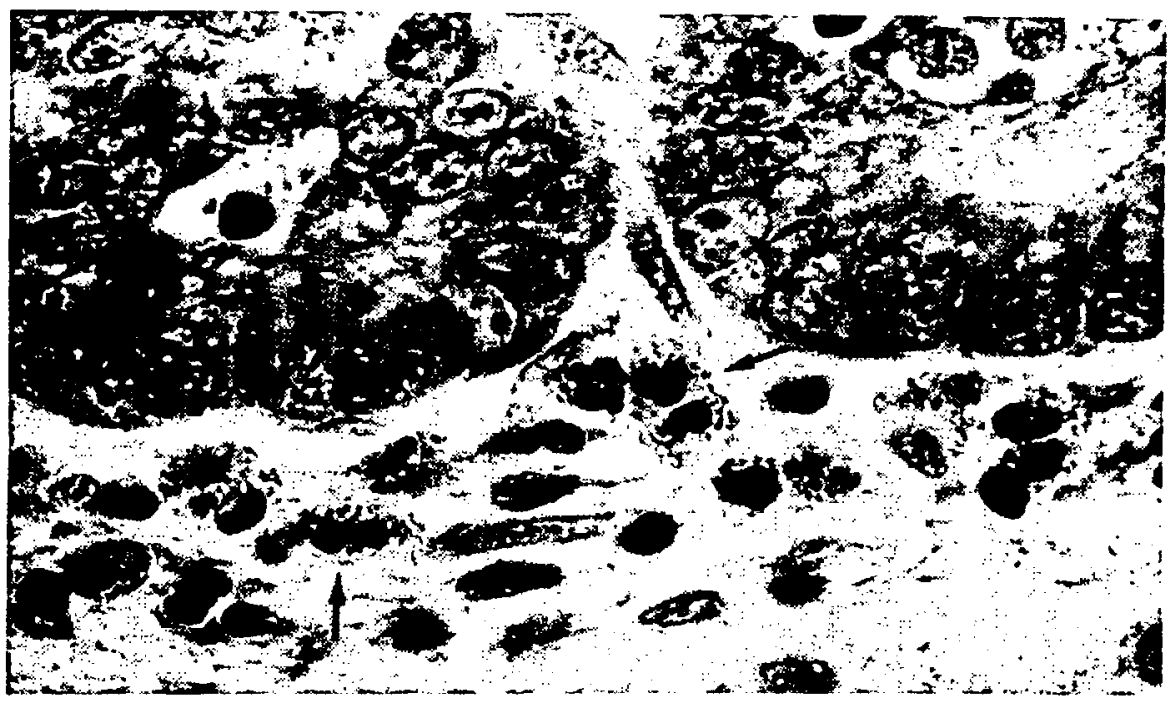

Figure 2. Eosinophil granulocytes in lamina subglandularis (arrows). Congo red. $x 1180$ ). Şckil 2. Lamina subglandularis'de eozinofil granulositler (oklar) Congo red. x 1180 ).

at the base of the villus (Figure $3 \mathrm{~A}$ ). It was also observed that some eosinophil granulocytes were present within intcstinal lumen (Figure 3B).

The pyroninophilic cells were identified in jejunum, cspecially in villus intestinalis intensively. But they were found also in crypts in a lesser extent (Figure 4).

Eosinophil granulocytes and plasma cell counts per VC unit is given in Table 3.
The statistical evaluation of the data showed that the difference of the mean values for eosinophil granulocyte and leukocyte concentrations found in peripheral blood were not statistically significant. Also, the difference of plasma cell counts in tissues were not statistically significant. But the difference between mean tissue eosinophil granulocytc counts of dogs with parazites in feces and those showing no parazites were significant $(p<$ 0.05)(Tablc 3). 

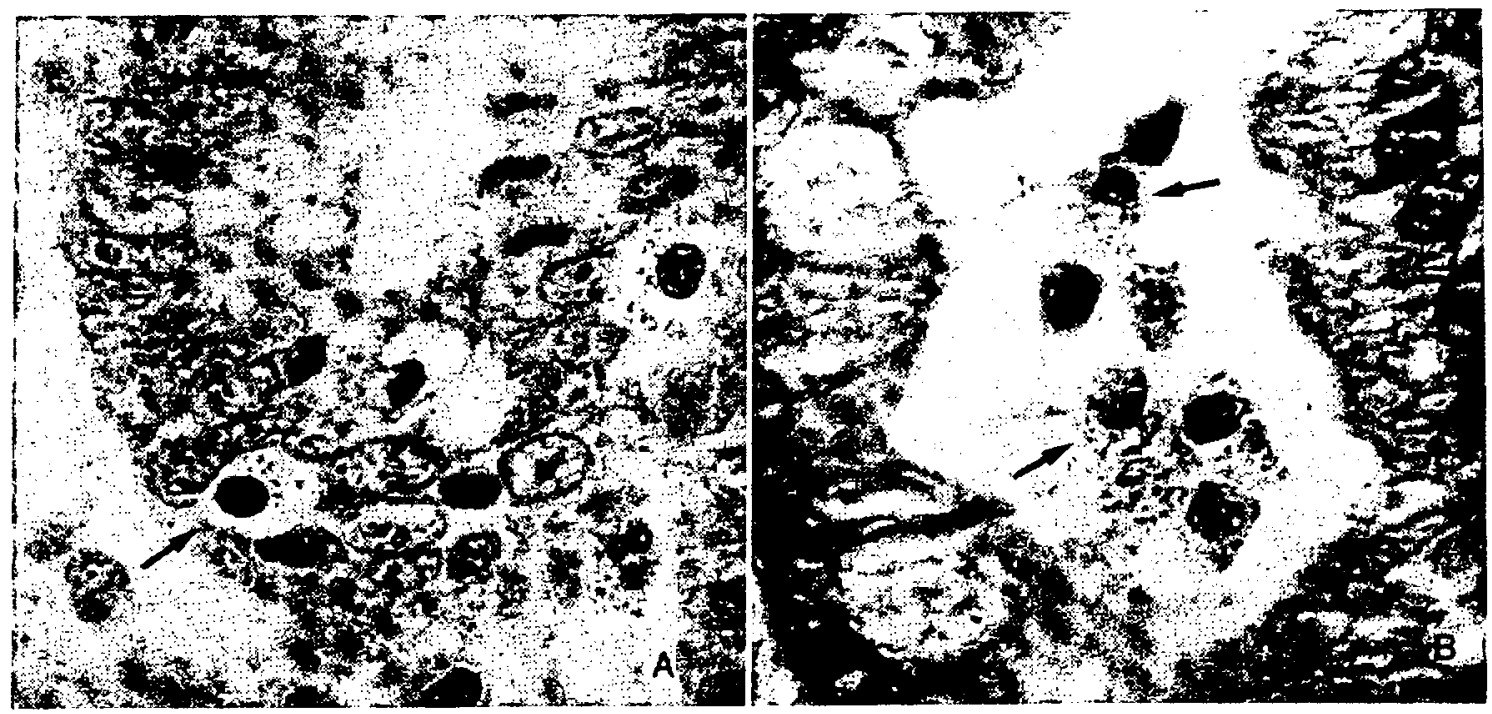

Figurc 3. A. Intracpithclial cosinophil granulocytes (arrow). Congo red. $x 12(x)$. B. Eosinophil gramulocytes in intestinal lumen (arrows). Congo red. $x 1180$.

Şckil 3. A. Intracpiteliyal cozinofil granulositler (ok). Congo red. x1200. B. Barsak lumeninde cozinofil granulositler (oklar) Congo red. $x 1180$.

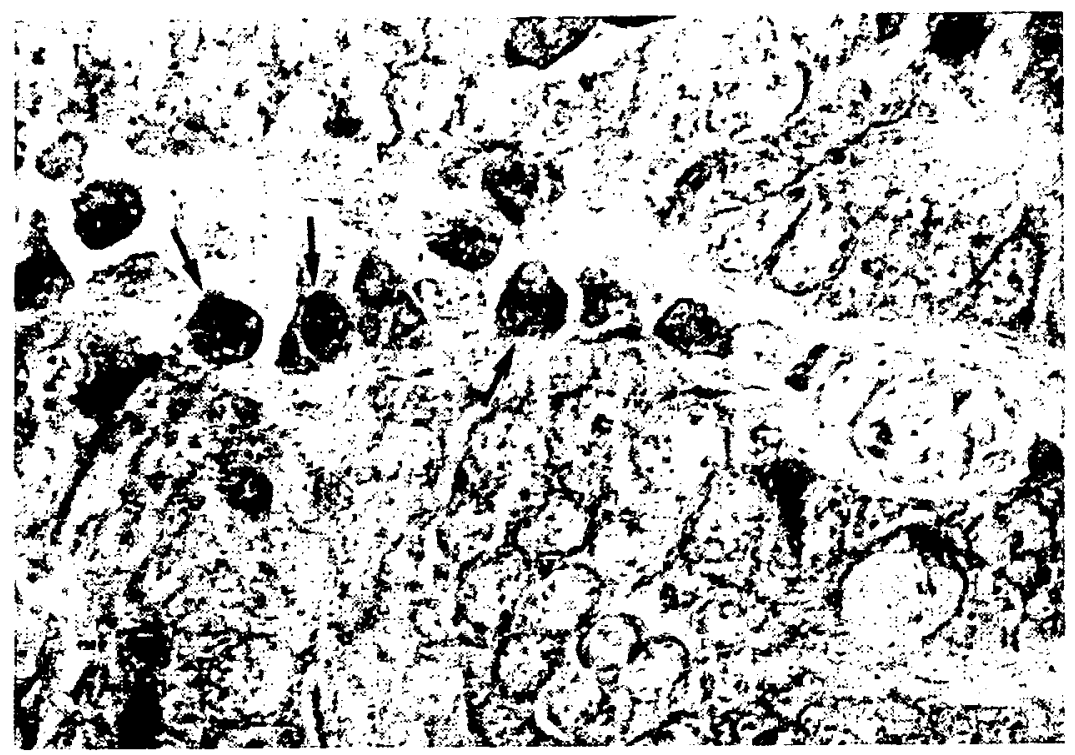

Figure 4. Plasma cells in villus intestinalcs (arrows). Methyl green pyronin $x 1220$.

Sekil 4. Villus intestinalis'de plazma hücreleri (oklar). Methyl grcen pyronin x 1220 .

Table 3. The cosinophil granulocytes and pyroninophilic cell counts in VC unit in the jejunal mucosa of dogs (means with SEM)

Tablo 3. Köpeklerde jejunum mukozasında, villus-kript ünitede plazma hücresi ve cozinofil granulosit sayıları

\begin{tabular}{|c|c|c|c|c|c|c|}
\hline \multirow[t]{2}{*}{ Groups } & \multicolumn{3}{|c|}{ Eosinophil granulocytes } & \multicolumn{3}{|c|}{ Plasma Cells } \\
\hline & $\mathrm{X}$ & \pm & SEM & $x$ & \pm & SEM \\
\hline Group I (n=7) & $133.26^{*}$ & & 11.90 & 90.91 & & 13.50 \\
\hline Group II $(n=4)$ & $72.07 *$ & & 18.90 & 72.15 & & 24.40 \\
\hline
\end{tabular}




\section{Discussion}

The present study provides information about distribution of eosinophil granulocyte and plasma cells within the jejunal mucosa of dogs with or without intestinal parasites.

There are relative little studies about the distribution of eosinophil granulocytes and plasma cells in the body under physiological or physiopathological conditions, and only a small part of these studies were concerned with the distribution of these cell types within intestinal wall $(15,22,23,40,43)$.

Experiments in the mice $(7,11,14,41$, $46)$, rats $(24,25,27,29,39)$, guinea pigs (16), turkeys (8), sheep (19) and human (9) have shown that infections with helmints and protozoan parasites are associated with pronounced intestinal mastocytosis, eosinophilia, plasmacytosis and increased antibody production.

In this study a significantly higher intestinal eosinophil granulocyte population in dogs naturally infected with intestinal parasites werc determined. The eosinophil granulocytes were observed intensively in lamina propria of jejunal mucosa, especially within villus intestinales, in basal parts of crypts and in lamina subglandularis. Furthermore, eosinophil granulocytes were located intraepithelially in crypts and rarely at the base of the villus. It was also observed that some eosinophil granulocytes had bcen passed in intestinal lumen. These findings are in accordance with earlier studies stating that cosinophil granulocytes in intestinal tract are located mainly in lamina propria $(3,5,21)$. Also, the increase of the numbers of eosinophil granulocytes in jejunum of parasitized dogs confirms the previous findings about response to parasitic agents of intestinal mucosa $(14,16$, $34,41,42)$.

In sheep infected with Trichostrongylus colubriformis, increases in the populations of $\operatorname{IgA}$ - and IgG1-containing plasma cells in the lamina propria was identified (2). Morever, the distribution of plasma cells in intestinal mucosa with Toxacara canis and Ancylostoma caninum infected dogs were also described $(26,35)$. Soh and Kim (35) suggested that more plasma cells occurred only in the villi intestinales. In this study, the plasma cells were seen especially in villus intestinales intensivcly, but they were found also in crypts in a lesser extent. However, the increase of plasma cells in intestinal tract in respons to the intestinal parasites described by different authors $(2,35)$ was not supported by this study, than the plasma cells in jejunal mucosa of dogs with intestinal parasites did not differe significantly from those without parasites. But it is in good agreements with the results of Lloyd et al (26) who observed no changes in plasma cell numbers during infection with Toxacara canis in puppies.

On the other site, the statistical evaluation of the data showed that the difference of the mean values for eosinophil granulocytes and lcukocytes of peripheral blood are not statistically significant. These results also confirm the previous study results about leucocyte formula and gastrointestinal parasites in goats (30).

In summary, we have identified distribution of eosinophil granulocyte and plasma cells within jejunal mucosa of dogs with or without intestinal parasites.

\section{References}

1. Ackerman SJ, Gleich GJ, Loegering DA, Richardson BA, Butterworth AE (1985) A compurative toxicity of purified human eosinophil granule cationic proteins for schistosomula of Schistosoma mansoni. J Trop Med Hyg, 34, 735-745.

2. Adams DB, Merritt GC, Cripps AW (1980) /ntestinal lymph and the local antibody and immunoglobulin response to infection by Trichostrongylus colubriformis in sheep. Aust J Exp Bio Mcd Sci, 58. 167-177.

3. Archer RK (1968) The eosinophil leukocytes. Scr Haematol, 1. 3-32.

4. Aschkenasy A (1971) Nutrition et Hémutopoïesis. C N Roy Soc, Paris. 
5. Butterworth AE (1977) The eosinophil and its role in immunity to helminth infection. Current Topics Immunol. 77, 127-169.

6. Butterworth AE (1984) Cell-mediated damage to helminths. Adv Parisitol. 23, 143-235.

7. Carroll SM, Grove DI, Heenan PJ (1986) Kinetic:s of cells in the intestinal mucosa of mice following oral infection with Ancylostoma ceylanicum. Inter Arch AlIcrgy App Immunol, 79, 26-32.

8. Cooper GL, Shivaprasad HI, Bickford AA, Nordhausen R, Munn R.J, Jeffrey JS (1995) Enteritis in turkeys associated with an unusual flagellated probzoan (Cochlosoma anatis). Avian Dis, 39, 183-190.

9. Croese J Loukas, Opdebeeck A, J, Provic P (1994) Occult enteric infection by Ancylostoma caninum. A previously unrecognized zoonosis. Gastroenterology. 106, 3-12.

10. Culling CFA, Allison RT, Bar WT (1985) Cellular Pathology Technique. Butcrwords, London.

1 I. Dent IA, Daly CM, Mayrhofer G, Zimmerman T, Hallett A, Bignold I.P, Creaney J, Parsons JC (1999) Interleukin-5 transgenic mice show enthanced resistance to primary infections with Nippostrongylus brasiliensis but not primary infections with Toxocara canis. Inlect Immun. 67, 989-993.

12. Egesten A, Alumets $O$, von Mecklenburg C, Palmegren M, Olsson I. (1986) Localization of cationic protein. inajor basic protein, and eosinophil perovidase in human eosinophils by immunoelectron microscopic technique. J Histochem Cytochem, 34, 1399-1403

13. Eren Ü, (iüzel $\mathbf{N}$, Türkütanıt $S$, Durukan A, Ergüldürenler \$, Kara E (20)(0) Köpeklerde barsak mukozasinda inast hücreleri. Ankara Üniv Vot Fak Derg, 47. $21-30$.

14. Faulkner H, Humphreys N, Renauld JC, Snick J van, Grencis R, van-Snick J (1997) Interleukin-9 is involved in host protective immunity to intestinal nematode infection. Eur J Immunol, 27, 2536-2540.

15. German AJ, Hall FJ, Day MJ (1999) Analysis of leucocyte subsets in the canine intestine. J Comp Path, 120. $129-145$.

16. Gleich G.J, Olson GM, Herlich H (1979) The effect of antiserum to eosinophils on susceptibility and acquired immunity of the guinea-pig to Trichostrongylus colubriformis. Immunology, 37, 873-880).

17. Grouls V, Helpap B (1981) Selective staining of eosimphils and their immature precursors in tissue sections and autoradiographs with Congo red. Stain Technol, 56, 323-325

18. Hart IR (1979) The distribution of immunoglobulincontaining cells in canine small intestine. Res Vet Sci. 27. 269-274

19. Huntley JF, Wallace GR, Miller HRP (1982) Quantiative reccoven of isolated mucosal mast cells and globule leucocytes from parasitised sheep. Res Vet Sci. 33. 58-63.
20. Ishikawa T, Dalton AC, Arbesman CE (1972) Phagocytosis of Candida albicans by eosinophilic leukocytes. J Allergy clin Immunol. 49. 311-315.

21. Jain NC (1986) Schalm's Veterinary Hematology: Leat \& Febiger, Philadelphia.

22. Jergens AE, Moore FM, Kaiser MS, Haynes JS, Kinyon JM (1996) Morphometric evaluation of im. munoglobulin A-containing and immunoglobulin $G$ containing cells and $T$ cells in deodenal mucosa from healty dogs and from dogs with inflammatory bowel disease or nonspecific gastroenteritis. Am J Vet Res 57, 697-704.

23. Kazura JW, Mahmoud AAF (1983) Protective Role of Eosinophils: The Schistosome Egg Granuloma. 383395. In: T. Yoshida and M. Torisu (Eds.): Immunobiology of the Eosinophil. Elsevier Science Publishing Co Inc, New York.

24. Kelly JD, Ogilvie BM (1972) Intestinal mast cell and eosinophil numbers during worm expulsion in nulliparous and lactating rats infected with Nippostrongylus brasiliensis. Inter Arch Allergy App Immunol, 43, 497-509.

25. Lindsay MC, Blaies DB, Williams JFSO (1983) $T_{\text {(t- }}$ enia taeniaeformis: Immunoglobulin E-comtaining cells in intestinal and lymphatic tissues of infected rats. Inter J Parasitol, 13, $91-99$.

26. I.loyd MK, Wijensundera S, Soulsby E.JI (1991) /htestinal changes in puppies infected with Toxocara canis. J Comp Pathol, 105, 93-1(1)4.

27. Miller HRP, Jarrett WFH (1971) Immune reactions in mucous membranes. I. Intestinal mast cell resonse during helmint expulsion in the rat. Immunology, 20. 277- 288.

28. Mills JN, Valli VEO (1988) The Hemopoiefic System. In: W.F. Robinson and C.R.R. Huxtablc (Eds.): Clinicopathologic Principles for Veterinary Medicine. Cambridge University Press. Cambridge. New York.

29. Moqbel R, King SJ, Macdonald AJ, Miller HRP, Cromwell O, Shaw R.J, Kay B (1986) Enteral and systemic release of leukotrienes during anaphylaxis of Nippostrongylus brasiliensis-primed rats. J Immunol, 137, 296-301.

30. Palacio MJF, Montes CAM, Vega FDA, Del-Palacio MJF, De-Vega FDA (1985) Relation between leukocyte formula and gastrointestinal parasites in goats. Rev Clin Esp, 1. 137-139.

31. Peters MS, Rodriguez M, Gleich GJ (1986) L calization of human eosinophil granule major basic protein, essinophil cationic protein, and eosinophitderived neurotoxin by immunoelectron inicroscopic technique. Lab Invest, 54. 656-662.

32: Pilot ML (1950) Use of base in fluids for counting eo sinophils. A method for staining cosinophils. Am J Clin Pathol. 20, 871-872.

33. Ross MH, Reith E.J, Romrell LJ (1989) Histolog!. ^ Text and Atlas. Williams and Wilkins, Baltimorc.

34. Ruitenberg EJ, Elgersma A, Kruizinga W, Leenstra F (1977) Trichinella spiralis infection in congenitally athymic (nude) mice. Parasitological, se- 
rological and haematological studies with observations on intestinal pathology. Immunology, 33, $581-587$

35. Soh CT, Kim SJ (1973) Changes of intestinal mucous membrane of dog with reference to the immunological response to parasite infestation. Yonsci Med J, 4, 27 36.

36. Spry C.JF (1988) Eosinophils. A Comprehensive Review and Guide to the Scientific and Medical Literature. Oxford Medical Publications, Oxford University Press, Oxford, New York.

37. SPSS Advanced Statistics ${ }^{\mathrm{TM}}$. 7.5. (1977) SPSS Inc. Chicago.

38. Sullivan TJ (1979) The role of eosinophils in inflammatory reactions. Prog Hematol, 11, 65-82.

39. Taraschewski H, Sagani C, Mehlhorn H (1989) Ultrastruciural study of the host-parasite interface of $\mathrm{MO}_{\mathrm{O}}$ niliformis moniliformis (Archiacanthocephala) in laboratory-infected rats. J Parasitol. 75, 288-296.

40). Torisu M, Iwasaki K, Tanaka J, Lino H, Yoshida T (1983) Anisaki and Eosinophi: Pathogenesis and Biologic Significance of Eosinophilic Plegmon in Human Anisakiasis. 343-367. In: T. Yoshida and M. Torisu (Eds.). Immunobiology of the Eosinophil, Elsevier Science Publishing Co Inc. Ncw York.

41. Tronchin G, Dutoit E, Vernes A, Biguet J (1979) Oral immunization of mice and metabolic antigens of
Trichinella spiralis larvat: Effects on the kinetics of intestinal cell response including mast cells and polymorphonuclear eosinophils. J Parasitol, 65, 685-69!.

42. Wilkes SD, Goven AJ (1984) Tissue eosinophil num bers and phospholipase $B$ activity in mice infected with Trichinella spiralis. Int J Parasitol, 14, 479-482.

43. Willard MD, Leid RW (1981) Nonuniform horizontal and vertical dstributions of immunoglobulin A cells in canine intestines. Am J Vet Res, 42, 1573-1580.

44. Wirth D (1950) Grundlagen Einer Klinischen Hämatologie der haustiere. Urban \& Schwarzenberg. Wien und Insbruck.

45. Yazdanbakhsh MA, Tai PC, Spry CJF, Gleich GJ, Roos D (1987) Synergism between eosinophil cationtic protein and oxygen metabolites in killing of shistosomula of Schistosoma mansoni. J Immunol, 138. 3443-3447.

46. Yin JG, I, DC, Zhang XC, Zhou CF, Yang J, Li JH (1998) Inmune response of intestinal mucosa to in. fection with Cryptosporidium parvum in mice. Chincse J Vet Sci, 18, 254-256

Yazışma Adresi:

Doç: Dr. Ülker EREN

Adnan Menderes Üniversitesi

Veteriner Fakültesi

Balı Kampüsü Isılklı/AYDIN 